\title{
Televizyon Haberlerinde Gerçeğin Yitimi: "Yeniden Üretilen" Savaş ve Çatışma Haberlerinin Profesyonel Gazetecilerin Gözüyle Analizi
}

\author{
Naciye Beril EKŞİOĞLU SARILAR*
}

\begin{abstract}
ÖZ
Modernleşmenin yaklaşık iki yüzyıllık macerasında teknolojik gelişmeler insanın algılarını değiştirmiş, göze ve dolayısıyla görüntüye büyük bir önem atfetmiştir. 19. yüzylldan itibaren kamusal insanın izleyiciye evrilmesiyle; görmek, eylemde bulunmanın önüne geçmiştir. Etkinliğini kaybeden insan edilgen izleyiciye dönüşmüştür. Jean Baudrillard'ın teorisinden yola çıkarak, bilgi edinme aracı olan haber gerçeklikten yoksun yeni bir gerçeğe, televizyon stüdyolarında hiper-gerçeklik (hyperreality) olarak inșa edilmektedir. Bunun bir örneği de stüdyo ortamında artırlmış gerçeklik uygulamalarıyla sunulan haberlerde görülmektedir. Baudrillard'ın "suret artık gerçeğin kopyası değil, gerçeğin ta kendisidir" tezinden hareketle burada tartısılan konu; bizatihi gerçeğin yansıtılmasına odaklanan, politik kararları etkilemesi beklenen haberin, artırılmış gerçeklik stüdyolarında hazırlanmış ve "oyunlaştırılmış" bir sunumla, kamuoyunun demokratik hak ve taleplerinin ifadesi olan bilgi edinme hakkını karşılayabilecek olup, olmamasıdır? Dolayısıyla çalışmada televizyonlardaki artırılmış gerçeklik uygulamalarıyla "yeniden üretilen" savaş/çatışma haberciliğinin analizine odaklanılmıştır. Artırılmış gerçeklik uygulamaları bahsiyle literatür taraması yapıldığında, çalışmaların genel izleğini tanımlamalar ve uygulamanın birçok sektöre yaptığı katkılar oluşturmaktadır. Genel çalışmaların aksine, bu çalışma artırılmış gerçeklik özelinde teknolojik uygulamaların her sahada müspet ifadesini bulamayacağı varsayımına dayanmakta ve bunu savaş/çatışma haberciliğinin televizyon stüdyolarındaki sunumu üzerine temellendirmektedir. Bu minvalde çatışma/savaş muhabirliğinde uzmanlaşmış gazetecilerle; okur temsilcisiyle, haber sunucusuyla, veri gazetecisi ve savaş ortamlarının tanıklı̆̆ını yapmış iki akademisyenle derinlemesine mülakatlar yapılarak artırılmış gerçeklik uygulamalarının izleyicide yaratabileceği etkiler sorgulanmiştır.
\end{abstract}

Anahtar Kelimeler: Savaş/Çatışma, Televizyon Haberleri, Gerçeğin Yitimi, Şiddet, Teknoloji, Artırılmış Gerçeklik, İmaj.

\section{The Loss of Reality in News: The Reconstruction of War and Conflict News Analysed by Professional Journalists}

\begin{abstract}
In the nearly 2 century long history of modernization, technology has changed the perception we have on our surroundings and it has given the sense of vision a greater emphasis. Starting from the 19th century acting has lost its importance to spectating. The active individual has transformed into the passive spectator. The news is the information learning tool of the public and just like in Jean Baudrillard's theory, the news loses it's reality and transforms into hyperreality. An example of this is seen with the usage of augmented reality in news studios. In this article, the new perception of war/conflict journalism that has risen with the use of augmented reality has been analysed. Articles written on the subject of augmented reality usually focus on it's advantages on multiple sectors. In contrast to them, this article focuses on the fact that augmented reality usage may not be beneficial in all sectors and bases this on it's use in conflict/war journalism. For this analysis, four experienced conflict journalists, a data journalist, an ombudsman, a television news reporter and 2 academics one of which has a military background and the other a journalistic one have been interviewed.
\end{abstract}

Keywords: War/Conflict, News, Loss of Reality, Violence, Technology, Augmented Reality, Image.

\section{Giriş}

Aydınlanma çağında ilk kez farkına varılan "beden-zihin ikiliğ̣” sorunsalına ilişkin tartışmalar günümüzde de devam etmektedir. Pozitivist geleneğe göre; zihin, bir tür öz farkındalıkla ilişkilendirilerek beden ile arasındaki ikilik maddesel bir töz olarak tanımlanmaktadır (Robinson, 2003). Böylece göze bir çeşit üstün duyu organı olma niteliği atfedilirken, gündelik hayatta "hakikat ancak görülebilendir" mottosu güç kazanmıştır. Günümüzde görme ediminin ağırlık kazandığı enformasyon teknolojileri alanında öne kullanılan her yeni araçla; beden, alg1, zaman ve mekân üzerinden yeni ilişkiler kurulmaktadır. Bu minvalde gazetecilik ve habercilik alanlarında kullanılan farklı anlatı biçimleri sayesinde gerçekliği vurgulamaya yönelik teknik yenilenmeler büyük bir istekle uygulamaya alınmaktadır. Sözgelimi geleneksel habercilikte kullanılan kaynaktan izleyiciye doğru akan doğrusal anlatı, iki boyutlu ekran görüntüsünün üç boyutlu hale

* Dr. Öğr. Üyesi, İstanbul Aydın Üniversitesi, nberilsarilar@aydin.edu.tr Makalenin Gönderim Tarihi: 11.03.2021; Makalenin Kabul Tarihi: 30.04.2021 
gelmesi nedeniyle izler kitleye "oradaymış" duygusu verebilmektedir (Sundar vd., 2017, s. 672). Bu durum geleneksel haber anlatımını (storytelling) zayıflatırken; izleyiciye ya da okuyucuya haberi yaşatma (storyliving) çabalarının hız kazanmasına neden olmaktadır (Maschio, 2017). Zira artırılmış gerçeklik teknolojisinin haber aktarım süreçlerinde yoğun olarak kullanılmasından kaynaklanan mekânsal yanılsama nedeniyle haberin aktarılmasında tercih edilen yöntemler, haber içeriğinden çok daha önemli hale gelmektedir.

Bu çalısmanın amacını yansıtan; artırılmış gerçeklik uygulamalarının izler kitle üzerinde görme edimini nasıl şekillendirdiğini anlama çabaları, bellekte oluşturabileceği kodlar üzerine yapılabilecek incelemeler, kültürel antropolojinin ilgi sahasında değerlendirilebilir. Ancak burada kavranmaya çalışılan kamuoyunun olaylara müdahil olmasında kilit rol oynayan, nesnellik iddiasında olan ve üstelik savaş ya da çatışma gibi bir ülkenin siyasal, ekonomik ve toplumsal alt yapısını etkileyen haberin teatral bir sunumla izlerliğini artırma çabası üzerinden haber stüdyolarındaki artırılmış gerçeklik teknolojisini değerlendirmektir. Bu nedenle çalışmanın başında bir saptama yapmakta fayda bulunmaktadır; İstanbul Aydın Üniversitesi Rektörlüğünün Sosyal Bilimler Etik Kurul Raporu'nun 27 no'lu karar izni ile yapılmış bu çalışma haber stüdyolarındaki artırılmış gerçeklik uygulamalarının izler kitle üzerindeki anlamlandırma sürecini seyirciler üzerinden değil; bu ortama bilfiil tanıklık eden profesyonel savaş muhabirlerinin görüşleri üzerinden temellendirmektedir. Çalışma kapsamında, savaş ve çatışma haberciliği konusunda uzman medya profesyonelleri: Coşkun Aral, Cem Tekel, Şerif Turgut ve Mete Çubukçu ile derinlemesine mülakat gerçekleştirilmiştir. Teknoloji-haber ilişkisinde yeni bir alan olarak ortaya çıan veri gazeteciliğinde uzman Pınar Dağ, ATV Haber sunucusu Mehmet Derindağ, savaş alanlarının tanıklığını yapmış ve uzun yıllar okur temsilciliği (ombudsman) görevini üstlenmiş gazeteci Faruk Bildirici ile biri televizyon gazetecisi diğeri asker kökenli iki akademisyenle yüz yüze derinlemesine mülakat yapılmıstır.

Çalsşmada haberin aktarılması bağlamında bir mesele olarak kavranan artırılmış gerçeklik uygulamalarının, kavramsal tanımlarının aksine habere konu gerçeğin zarar görüp, görmediği tartışılmıştır. Çalışmanın hipotezi çatışma/savaş haberlerinde artırılmış gerçeklik uygulamalarının kamuoyunu gerçeğe yakınlaştırmak yerine gerçekten kopardığı önermesine dayanmaktadır.

\section{Artırılmış Gerçeklik Perspektifinden Görme Ediminin Teorik Arka Planı}

Platon'un mağara alegorisinde insan hakikatin peşine düşmektedir. Dolayısiyla şeylerin gölgesi altındaki insanı ezeli hakikatin, adaletin, güzelliğin ve iyi gibi ideaların ne kadar cezbedebileceği antik dönemden beri sorgulanmakta ve tartışılmaktadır. Bu minvalde insanlar "gerçek nedir" sorusuna yüzyıllardır cevap aramışlardır. Gerçeği duyumsamakla ilintilenen göz duyusu kendi içinde bilişsel manada evrimsel sürecini yaratmıştır. Giovanni’nin İncil’i “Önce söz vardı" diye başlar (Sartori, 2004, s. 27). Ancak görüntü süreç içinde sözün yerini almıştır. Aristoteles ve Porphy gibi antik dönem yazarları gözün askeri bir stratejist gibi nesneleri tutsak aldığını öne sürmüşlerdir. Orta çağda perspektifin insan hayatına girmesiyle, göz bu atfedilen saldırgan konumundan çıkmıştır. Böylelikle ehil hale dönüşen gözü denetleyebilme imkânı doğmuştur (Florensky, 2001).

Görmenin ehlileştirilmesi teknoloji ile paralel bir seyir izlemiştir. Roland Barthes insan hayatına 19. yüzyılda giren fotoğrafin "kodsuz mesaj" ürettiğini bunun da görüntünün mekanik elde edilmesiyle doğallık mitine dönüştüğünü, bir başka deyişle kaçınılmaz nesnelliğini vurgulamaktadır. Ancak Barthes önemli bir saptama da yapar: tarihsel bir paradoksla teknoloji bilginin, imajların dağılımını artırdıkça, verilerin altındaki anlam dünyasını maskeleyen araçları da üretmiştir (Barthes, 2001, ss. 40-41). Aydınlanma çağı ile görüntünün artan önemi karşısında görüşler ikiye ayrılmış: kimi düşünürler görselliğin bilişsel süreci zenginleştirdiğini savunarak pozitif perspektiften değerlendirmiş, kimileri de özellikle medyada hâkim olan görselliğin bireyi zayıflattığını öne sürmüştür. Bu bakış açısına göre; eylemsizliğe mahkûm insan artık gören değil bakan, baktığını eylemle pekiştiremeyen ve sunulanı genellikle sorgulamadan kabullenen bir varlık haline gelmiştir.

René Descartes'ın "Düşünüyorum öyleyse varım" cümlesi, teknolojinin tüm hızılla ilerlediği günümüzde düşünceyi geri plana atmış (Yıldız, 2013, s. 96), bireyin "gösterinin içinde oldukça varım" düșüncesine evrilmesine neden olmuştur. Fransız Marksist filozof Guy Debord "Gösteri Toplumu" (1967) isimli eserinde kapitalist dünyanın optik bir toplum olduğundan bahisle göz odaklı bir gelişim 
gösterdiğinden, gözün bireyi bilmek eylemine götüren duyu olduğundan bahseder. Gözün önemi arttıkça gösteri hız kazanmakta, düşünmek lüks ve zor bir süreç haline gelmektedir. Günümüzde bireyler renkli reklamlarla donatılmış, neon 1şıklı mekânları, moda adı altında renkli sunumları tercih etmeye başlamıştır. Hareket, renk, 1şık takipçisi göz gösterinin tutsağı oldukça, eylemsellikten uzaklaşmışıtır. Sartori’nin "Görmenin İktidarı" çalışmasında formüle ettiği gibi; "homo sapiens" yani bilen insan, görüntünün sesin önüne geçmesiyle "homo-videns" e yani gören insana dönüşür. Böylelikle enformasyon üretimi rolü toplumsal ilişkilerden, pasif alımlayan insanın her daim muhatap olacağı seyirlik görüntülere dönüşmüştür (Sartori, 2004).

Gösteri odaklı yaşamak, "yaşamı bir düş uğruna terk etmek” Kevin Robins’e göre içinde yaşanılan dünyayla ilgili bir hastalık belirtisidir; "Var olan dünyanın algılanan yetersizliklerinden hoşnut olmama" durumunun neden olduğu bir "hoşnutsuzluğu önleme stratejisidir" (Robins, 1999, s. 81). Buna göre bireyin, doğrudan kavramakta yetersiz kaldığı dünyayı çeşitli araçlar dolayımıyla görmeye zorlayan gösteri, doğal olarak görmeyi de en ayrıcalıklı insan duyusuna çevirmektedir (Debord, 1996, s. 97). Böylece geçmişte dokunma aracillğıyla elde edilen soyut ve mistik hislenmenin yerini görme almaktadır. Gösteriyle gerçeğin iç içe geçişi, yeni bir gerçeklik eşiği yaratmaktadır. Yeni gerçeklik bir anlamda gösterinin tıpkısıdır. Guy Debord'a göre zihinleri teslim alan gösteri, insanların olup bitenleri görmezlikten gelmesine ve yine de anlaşılan bir şey varsa bunu derhal unutturmayı büyük bir ustalıkla başarmaktadır. İmajın nesnellik iddiasını eleştiren Debord'a göre; gösterisel ilişkilerin fetişisttik, saf nesnel görünümü, aslında bunların insan ve sınıf arasında ilişkiler olduğu gerçeğini gizlemektedir (Debord, 1996, s. 131).

Diğer yandan yirminci yüzyllın ikinci çeyreğinden itibaren yapılan çalışmalarda televizyonun kamu üzerindeki etkilerine odaklanılmıştır. Çağdaş kuramcılardan Neil Postman (1985) “Televizyon Öldüren Eğlence" kitabında; televizyonu gösteri dünyasının ortasına yerleştirerek, rasyonel edimler üzerindeki yıkıcı etkisinden bahsetmiştir. Kitle iletişim teknolojilerinin tarafsız olmadığ1 ve insan varoluşunu değiştirdiği önermesini sunan enformasyon çağını yorumlayan düşünürlerden Marshall Mc Luhan'dan etkilenen Baudrillard'a göre bugünün insanı, doğrunun peşinde koşan bir erdem projesi değil, fikir ve imgeleri tekrar tekrar üreten bir makinedir (Bowdon, 2018, s. 19). Yirminci yüzyllın son çeyreğinden itibaren Batı toplumundaki dönüșümleri simülasyon, simülakr, hiper-gerçeklik gibi metaforlar üzerinden tarif eden Jean Baudrillard; teknoloji çağında ekranlarda seyrettiklerimizin gerçeklikten sıyrılmış, simülasyon evreninde inşa edilmiş "hiper-gerçeklik" olarak tanımlamaktadır. Baudrillard'a göre modern birey, medyadaki sembol ve göstergeleri tüketerek sonsuz defa üretilen bir gerçeklik yaşamaktadır: "Burada ne bir imitasyon ne bir kopya ne de taklit söz konusudur; aslı yerine göstergeleri konmuş bir gerçekten bahsediyoruz" saptamasında bulunmaktadır. Bu durumda şu sorular sorulur: insan gerçeği mi, yoksa gerçeğin göstergelerini mi ister? Baudrillard insanın bu evrende daha çok haber ve bilgiye karşı daha az anlamlı bir hayat yaşadığını savunmaktadır. Baudrillard'ın "simülasyon teorisine" göre postmodern çağda kapitalizm evrilmiş, Batı dünyasında gerçeklik anlamını ve buna müteakip varlı̆̆ını yitirmiştir. Bildik anlamda kapitalizm de sosyalizm de günümüz dünyasında insanların yaşam pratiklerini, kültürlerini, ekonomilerini düzenlemede yeterli olmamaktadır. Umudunu yitirip çaresiz kalan insanın yeni bir dünya bir başka söylemle "simülasyon evreni”" yaratmaktan başka şansı kalmamıştır. Buna göre "hiper-gerçeklik"e (hyperreality) geçiş dört evreden oluşmaktadır: birinci evrede göstergeler gerçekliğin yansıması olarak gelişmektedir; ikinci evrede göstergeler henüz gerçeğin yerini almasa da hakikati abartarak, çarpıtarak dönüştürmeye çalısmaktadır; üçüncü ve dördüncü evrede ise göstergeler hakikati tümüyle ele geçirip, kendi varlığını inşa etmektedir. Bu aşamada toplum simülasyon ve göstergelerin yer aldığ1 sembolik bir topluma dönüşmektedir. Toplum artık insanlar arasındaki ilişkilerin bile sembollerden oluştuğu simülakrum ya da başka bir deyişle taklitler topluluğudur. Baudrillard'a göre toplumda hakikatin yerini semboller, sanal gerçeklik ve imajlar almıstır. Yaratılan yeni evrende insanlar her şeyi gerçek gibi algilasa da gerçek tümüyle imajlardan oluşan kurgusal bir düzlemde gözlerimizin önünden kaymaktadır. Bu nedenle Baudrillard hemen her şeyin sanal olarak yaşandığı, mesafelerin belirsizleştiği, gerçek ile düş arasındaki sınırların yok olduğu, herkesin aynı sanallığı bir simülakr bombardımanı alında yaşadığı bir dünyadan bahseder. Buna göre teknoloji simülasyon ortamının kendisidir (Güngör, 2011).

Baudrillard kendi perspektifinden tarihsel süreci değerlendirirken; birinci simülakra dönemini Rönesans ile, ikinci simülakra dönemini Sanayi Devrimi ile, üçüncü simülakra çağını ise medya ve bilişim teknolojileri 
ile ilişkilendirmektedir. Böylece televizyon kanallarının gösterişli haber stüdyoları simülasyon evreninin bir parçası olarak kavranmakta ve başta savaş ya da çatışma gibi insan hayatını ilgilendiren kimi önemli olaylar televizyon haber stüdyolarında kullanılan artırllmış gerçeklik gösterileri sayesinde hılı birer imge haline dönüşmektedir. Fransız düşünür Paul Virilio, Nazi Almanya’sında rejimin, insanları sokaktan uzaklaştırma ve ayaklanmadan uzak tutmanın yolunu bir paradoks şeklinde tanımladığ1 "yolları vaat ederek ve Alman halkına Volkswagen oto aldırmakta" bulduğuna işaret etmiş ve mobilite ya da hızın insanı eylemsizliğe iten yönünü vurgulamıştır (Virilio, 1998, s. 30). Buna göre; modern hayatın ilerleme arzusundan beslenen kuşatıcı gündelik hayat pratiği, insani deneyimlerin sığlaşmasına neden olmakta ve bireyin öznesi olamadığı yeni bir dönemin kapıları aralanmaktadır. Böylece iradesi dışında gelişen olayların çılgınca akışı içinde modern birey, sadece izlemekle yetinmekte ve teknoloji ve hızın belirleyicisi olduğu gelişmeleri anlamlandıramayacak kadar pasif bir tutum içinde kalmaktadır (Sadakaoğlu, 2020, ss. 204-214).

İtalyan siyaset bilimci Giovanni Sartori ise yazılı ya da sözlü olsun kelimenin içeriğinden televizyondaki görüntüye kayılmasını "tele-görmek" şeklinde tarif eder. Diğer kitle iletişim araçları gibi tele-görme de bilgiyi eksik ve tahrif ederek aktarmaktadır. Ancak televizyonun diğer kitle iletişim araçlarından farkı, görüntünün yalan olması ihtimalinde bunun daha yıkıcı ve tehlikeli sonuçlara neden olabilmesidir (Sartori, 2004, ss. 25,77). Sartori televizyon görüntüleri üretirken insanın soyutlayabilme ve anlama yeteneklerini azalttığını öne sürmektedir. Sartori de Baudrillard ve diğer teknolojiye eleștirel perspektiften bakan düşünürler gibi televizyonu ekranda yansıtılan gerçekdışı bir ortam olarak tanımlamaktadırlar (Sartori, 2004, s. 24): "Yapaylık ve simülasyonlar, gerçekliğin olanaklarını sonsuz biçimde çoğaltmalarına karşın asla gerçeklik değildir."

Medya etnografisi ise medya teknolojileriyle yaratılan metinsel içerikler yerine medyanın toplumsal etkilerini analiz etmeyi odak noktasına taşımıştır. Medya teknolojilerinin nötr olmadığını tartışan, iletişimin materyalliğini öne çıkaran Mc Luhann, Goody, Ong, Baudrillard ve Kittler gibi düşünürler her yeni aracin topluma bedenle, algiyla, zamanla, mekanla yeni ilişkiler empoze ettiğini öne sürmekte ve enformasyon yerine medyanın araçsallı̆̆ını anlamaya çalışmaktadır (Ginsburg vd., 2002, s. 19). Jenks (1995), görsel kültürü anlattığı kitabında, görsel formların iletişimsel kodlarla bağlantılı olduğundan bahseder; Batı toplumlarında bilişsel sürecin merkezine yerleşen gözün, bilmek ve görmek ekseninde tehlikelerini tartısıır.

Chicago Üniversitesi Sanat Profesörü W.J.T. Michelle dil ve kültürden sonra günümüzde görsellerle kuşatılmış dünyayı "resimsel dönemeç" (pictorial turn) şeklinde tanımladığı "görsel okuryazarlığın" açıklanmasında yeni formüllere olan ihtiyaca vurgu yapmaktadır (Mitchell, 1995). Michelle'in öne sürdüğü görsel okuryazarllğın açıklanmasındaki yeni formüllerin geliştirilmesi ise izleyicinin başta zihinsel olmak üzere duygusal süreçlerinin derinleştirilmesi olarak değerlendirilebilir.

\section{Savaş/Çatışma Haberciliği Özelinde Teknoloji ve Haber Anlatısının Değişimi}

Aydınlanma çağı ile başlayan görselin hakikatle olan bağlantısını, Amerikalı efsanevi haber sunucusu "anchorman" Walter Croncite'in (CBS- Evening News sunucusu) yirminci yüzyllın ortasında en çok tekrarladığ1 sloganla hatırlamak mümkün olabilir: "Görüntü yalan söylemez". Croncite’e göre televizyon gücünü, aktardığı görüntünün gerçeklik iddiasından almaktadır. Oysa kameranın yalan söyleyemeyeceğini öne süren bu görüşün tam tersini savunan ve kameranın yalan haber üretimine neden olabileceğini belirten göze ve görmeye ilişkin eleştirel yaklaşım ortaya koyanlar da vardır. Sözgelimi gerçeklik kavramını sorgulayan Fransız düşünür Baudrillard'ın medyanın tasarlanmış görüntülerin tutsağı olduğunu tezinden hareketle; teknolojinin desteğini alan haberin biraz eğlence, biraz da bilgi karışımından oluşan "infotainment" şeklinde sunulduğunu söylemek yanlış olmaz. Öte yandan, siyasal alanda güç elde etme mücadeleleri ve 1980 'lerden itibaren farklı sermaye gruplarının medya sektörüne girmesi ve televizyon kanallarının sahiplik yapısının değişimiyle birlikte haberin magazinleşmesi bir sorun olarak ortaya çıkmıstır. Görsel dilin gösteriye yönelik hızlı, parçalı, bağlamdan kopuk, basit ve yüzeysel anlatımı haberin yapısını değişmiştir. Hızlı kurgu, müzik ve çeşitli efekt teknikleri haberi dramatize etmekte, haberi gerçek bağlamından koparmakta ve bir dizi etik ihlali tartışmasını da beraberinde getirmektedir. Morris (2004) haberin dramatize edilmesinin, izler kitlenin ilgisini çekmekteki öneminden yola çıkarak, eğlence özelliğine değinmekte; White (2017) ise haber videolarındaki olayların yanlış yorumlanmaya müsait olduğundan bahsetmektedir. Değişen görsel dille birlikte bazı düşünürler televizyon habercilerinin sadece haberin 
öyküsünü (story) anlatan bireyler olmadığını aynı zamanda dünyayı da öykülendirilmiş yolla algılayan bireyler (storied) olarak yorumlamışlardır (Ergül, 2000, ss. 21-103). Haber öyküsünün aktarımındaki dramatizasyon, magazinleşmeyi de beraberinde getirmektedir. Sosyolog Ünsal Oskay (1998) "haberde magazini" şöyle tanımlamıştır: "Kadınların mayolu gösterimi değildir magazin (...) Dünyanın gerçekliğini olmadığı gibi betimlemek, o gerçekliği farklı biçimde tanımlamaktadır. (...) Magazin mitoslar gibidir. Ölümsüzdür. (...) Hayatın hiçbir yerine ve hiçbir şeyine tekabül etmez. Dolayısıyla hayatı açıklamayan bir açıklamalar yığınıdır”. Haberin doğasını bozan ve gerçeği olduğundan farklı şekillerde aktarma potansiyeline işaret edilen magazinin haberleştirilmesi gibi savaş ya da çatışmanın da haberleştirilmesinde benzer sakıncalara neden olabilmektedir. Sözgelimi tarihte ilk kez bir savaşın (Körfez Savaş1-1991) televizyon ekranlarından yayınlanması, izleyiciler nezdinde savaşı seyirlik bir gösteriye dönüştürmüş ve konforlu alanlarından tanık oldukları çatışmaları izlerken gerçekliğin eğilip bükülebilen yanına tanıklık etmiştir. Kevin Robins, "İmaj” isimli eserinde yüksek teknolojilerin savaşı algılama biçimimizi değiş̧tirdiğini aktarmaktadır. Robins düşman hedeflerine yapılanların görüldüğünü ancak bu 1slah edilmiş imajların neleri "temizlediğini”" veya "nötrleştirdiğini”" açılamadığını söylemektedir. Hatta bu durumu Robert J. Lifton’un makalesinden alıntıladığı "Silahlarımızın öldürücü olduğunu biliyoruz ama öteki taraftakilerin ölüm acısını hissetmeyi başaramıyoruz" cümlesiyle açıklamaktadır (Robins, 2013, s. 117).

Paul Virilio "tele-vizyon" yerine anında "tele-aksiyon" a geçildiğini (Sina, 1996), seyircilerin ve askerlerin "tele-topoloji" içinde girdiklerini, imajın içinde her iki grubun da gerçeklikten, gerçeğin ac1 verme potansiyelinden uzaklaştı̆̆ın belirtmektedir. Robins 1991 yılındaki Körfez Savaşı'nı şöyle tarif eder: "Görünür olan sesten, acı çekme duygusundan, yanık ve ölüm kokusundan ve tadından ayrılmıștır. Körfez Savaşı ekrandan bakılan bir savaştır". Robins savaş esnasında kameraya yansıyan görüntülerin izler kitle üzerinde gerçeklik kavramını kaybettirdiğini Körfez Savaşı'nda Amerikan Ordusu'nun başında olan General Schwarzkopf üzerinden anlatmaktadır. Schwarzkopf dünya medyasına, Irak'ta bir köprünün bombayla uçurulmasından az önce üzerinden geçen Iraklıya ait bir aracı göstererek espri yapmış ve "Şimdi size bugün Irak’taki en şanslı adamı göstereceğim.” demiştir. Körfez savaşını ekranlardan izleyen kitleyi tarif ederken John Berger; "Görebiliyorduk ama gördüklerimize karşı sağırdık. Gerçek dünyayla savaş1 dinlemenin, hissetmenin ve tepki vermenin gerçekliğiyle bağlarımız kopmuștu. İmaja çok fazla gömülmüş olduğumuz için ahlaki olarak kilitlenmiş ve nötrleşmiştik" demiştir (aktaran Robins, 2013, ss. 117- 118). Farklı çalışma alanları olsa da Körfez Savaşı esnasında enformasyon kamusal alan ilisskisini araştıran başka düşünürler de vardır: Morrison, Taylor ve Norris gibi. Morrison “Televizyon ve Körfez Savaşı” başlıklı çalışmasında; televizyonun ihtiyatlı olduğundan, uygun olanı gösterdiğinden ve izler kitlenin yüzde 86'llk kısmının zaten kendi "tatmin olma" duygusunun ötesine bakmakla ilgilenmediğinden, savaş haberlerine getirilen sınırlamaları anlayışla karşıladığından bahseder (Morrison, 1992). Philip Taylor ise "Savaş ve Medya" (1992) kitabında; müttefik güçlerin Saddam Hüseyin rejimine karşı yürüttüğü savaşın haricinde ikinci bir savaşın da medya savaşının olduğundan bahseder (Taylor, 1992).

Körfez Savaşı'nı Bağdat'taki bir otelin tepesinden CNN televizyon kanalı aracıllğıyla tüm dünyaya duyuran Amerikalı muhabirler savaşı; "muhteşem bir havai fişek gösterisi", "yüz binlerce ateş böceğì" benzetmeleriyle aktarmış; hassas ve lazer güdümlü füzelerin hedeflerini iğne deliğinden geçerek vurduğu sivillerden kimseye zarar gelmediğini kamuoyuna duyurmuştu (Arapkirli, 2017). ABD, Vietnam Savaş1 esnasında yaşadığı toplumsal sarsıntıları bir daha yaşamamak adına bu kez modern aklın faydacı pratiklerini devreye sokmuştur. CNN'e verilen yayın ayrıcalı̆̆ sayesinde savaş çok kansız, steril bir bilgisayar oyunu gibi aktarılmış, dahası tümüyle sivilleri korumaya yönelik edimlerden oluşan "insani” imaj üzerinden kurgulanmıştır. Böylece savaş gazeteciliği literatürüne sonraları epeyce sorgulanacak "iliş̧trilmiş gazetecilikembedded journalism" uygulaması girmiştir. Sosyolog Jean Baudrillard "Sessiz Yığınların Gölgesinde ya da Toplumsalın Sonu" eserinde haber ve savaş ilişkisi hakkında belirleyici fikirler ortaya atarken; Körfez Savaşı'nı evlerinde "bir dizi izler gibi deneyimleyen" (Baudrillard, 2019) kitlelerden söz etmektedir. Savaşın "pornografik" yanına dikkat çeken Baudrillard, bu durumun gerekçesi olarak medyanın "şiddet" olgusunu giderek daha fazla toplumsal seyirlik haline getirmesiyle açılamaktadır (Atay, 2019). 


\section{Savaş/Çatı̧̧ma Haberlerinin Artırılmış Gerçeklik Stüdyolarındaki Sunumu}

Makalenin çalışma konusu olan ve son yıllarda haber stüdyolarındaki sunumlarda kullanılan Artırılmış gerçeklik uygulamaları (Augmented Reality) Genişletilmiş gerçeklik (Extended Reality-XR) teknolojisinin bir alt unsurudur. Genişletilmiş gerçeklik, sanal gerçeklik (Virtual Reality-VR), karma gerçeklik (Mixed Reality-MR) ve artırılmış gerçeklik (Augmented Reality-AR) kavramlarını taşıyan bir şemsiye terim olarak kullanılmaktadır (Malcolm, 2019).

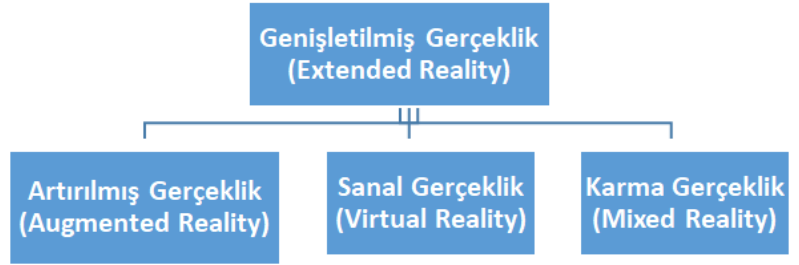

Artırılmış gerçeklik, duyusal unsurların gerçek zamanlı olarak zenginleşerek fiziksel dünya ile etkileşime girmesidir. Artırılmış gerçeklikte bilgisayar kaynaklı ses, görüntü, grafik ya da küresel konumlama sistemlerinden (GPS-Global Positioning System) elde edilen veriler mevcut gerçekliğe eklemlenerek/bindirilerek, ortamı zenginleştirmektedir. Bir başka deyişle, artırılmış gerçeklik teknolojisi sanal nesnelerin gerçek dünyaya eklenerek oluşturduğu yeni ortamdır. Ronald T. Azuma artırlmış gerçeklik teknolojisinin üç niteliğine vurgu yapmaktadır (Azuma, 1997, s. 362): Reel ortamda sanal ve gerçek varlıkların bir araya gelmesi, gerçek zamanlı interaktivite ve reel objelerle sanal objelerin uyumu. Diğer yandan gerçeklik teknolojilerini dijital ürünlerin varllğıyla gerçekliğin oluşturulması olarak tanımlayan yaklaşımlar da vardır (Milgram \& Kishino, 1994, s. 1322). Sanal gerçeklik; görüntü, ses, hologram gibi duyusal unsurların gerçek dünyanın simüle edilmiş (taklidi şeklinde) halinden oluşmaktadır. Buna göre kullanıcılar sanal gerçeklikte bulunmadığı bir mekân ya da ortamı bilgisayar ekranından üç boyutlu olarak deneyimleyebilir. Artırılmış gerçeklik teknolojisi ile dijital dünyanın nesneleri bireylerin gerçek dünyasına karışır, böylece bireyin gerçek dünyaya ilişkin algiları değişmektedir (Steurer,1992). Artırılmıs gerçeklik teknolojileri; video tabanlı ve optik tabanlı olmak üzere iki farklı platformda izlenebilmektedir (Azuma, 1997). Arttırılmış gerçeklik teknolojileri, sanal gerçeklik ve karma gerçeklikten oluşan genişletilmiş içerikler eğlence, eğitim, pazarlama, çalışma ve emlak gibi pek çok alanda kullanılmaktadır (Augmented Reality, 2017).

Artırllmıs gerçeklik görüntülemede optik projeksiyon sistemleri, monitörler, elde tutulan cihazlar ve kişinin üzerine takılan görüntüleme sistemleri dahil olmak üzere çeşitli teknolojiler kullanılmaktadır. Artırllmış gerçeklik teknolojileri arkeoloji, mimari, sanat, ticaret, inşaat, eğitim, oyun, tasarım, tıp, askeriye, futbol başta olmak üzere spor, navigasyon, çeviri ve televizyon gibi sayısız farklı alanda kullanılmaktadır (Unutmaz, 2017). Habercilikte ilk kez artırılmış gerçeklik teknolojisini benimseyen yayın organları The New York Times, USA Today, Wall Street Journal ve Boston Globe, Financial Times ve BBC'dir (Pavlik \& Bridges, 2013).

Sosyal bilimci Everett Rogers'a göre bir yeniliğin benimsenmesi için beş aşamadan geçmesi gerekir: Bilgi, ikna, karar, uygulama ve onay. Buna göre haberi tüketenlerin kullandığı bir teknoloji olması için "artırılmış gerçeklik teknolojisinin" de bu beş aşamayı geçmesi gerekmektedir. Rogers yeniliğin benimsenme ihtimalinin de beş aşamadan oluştuğunu söyler: Göreceli de olsa yeniliğin alg1lanan avantaj, uyumluluk, karmaşıklık veya basitlik, denenebilir olma ve gözlenebilir olma. Ancak medya yöneticileri tarafindan arttırılmış gerçeklik ile zenginleştirilmiş hikâyeler her alanda uygulandığı zaman bunun sonuçları görülebilecektir (Pavlik \& Bridges, 2013). Bu minvalde televizyon yayınlarında kullanılan artırlmış gerçeklik uygulamalarının esas amacı, yeni nesil izler kitlenin görüntü ile etkileşime girmesine olanak tanımaktır. Televizyon stüdyolarında ilk artırılmış gerçeklik uygulamaları hava durumu sunumlarında kullanılmıştır. Bu sunumlarda kameraların anlık ve eş zamanlı çektiği görüntüler, üç boyutlu grafik sembollerle birleştirilerek ortak bir sanal jeo-uzay modeliyle eşleştirilen görseller kullanılmıştır. Günümüzde futbol, yüzme, rugby ya da öteki spor etkinliklerinde hem sahanın bazı alanları hem de oyun alanına bindirilmiş ticari reklamları etkin kılabilmek için artırılmış gerçeklik uygulamalarından yararlanilmaktadir. 
Dijital teknolojiler günümüzde haber stüdyolarındaki sunumları değiştirmiştir. Haber stüdyolarında özel sensörlü kameralar sunucuyu takip etmekte, stüdyoda "greenbox" perde, sanal grafikler, sanal nesneler de yerleştirilerek haber sunumu yapılmaktadır. Artırılmış gerçeklikte sunucu bilgisayar tarafindan oluşturulmuş bir ortamda hem bedenini hem söylemini farklılaştırarak etkileşime girmektedir. Çalışmanın konusu olan "savaş/çatışma haberlerinin artırılmış gerçeklik stüdyolarındaki sunumu" son yıllarda bu teknolojinin en çok kullanıldığı haber alanlarından biridir. Aşağıdaki tabloda Türkiye dâhil dünyadaki savaş ve çatışma haberlerinin televizyon stüdyolarındaki sunumlarından örnekler alınmıştır.
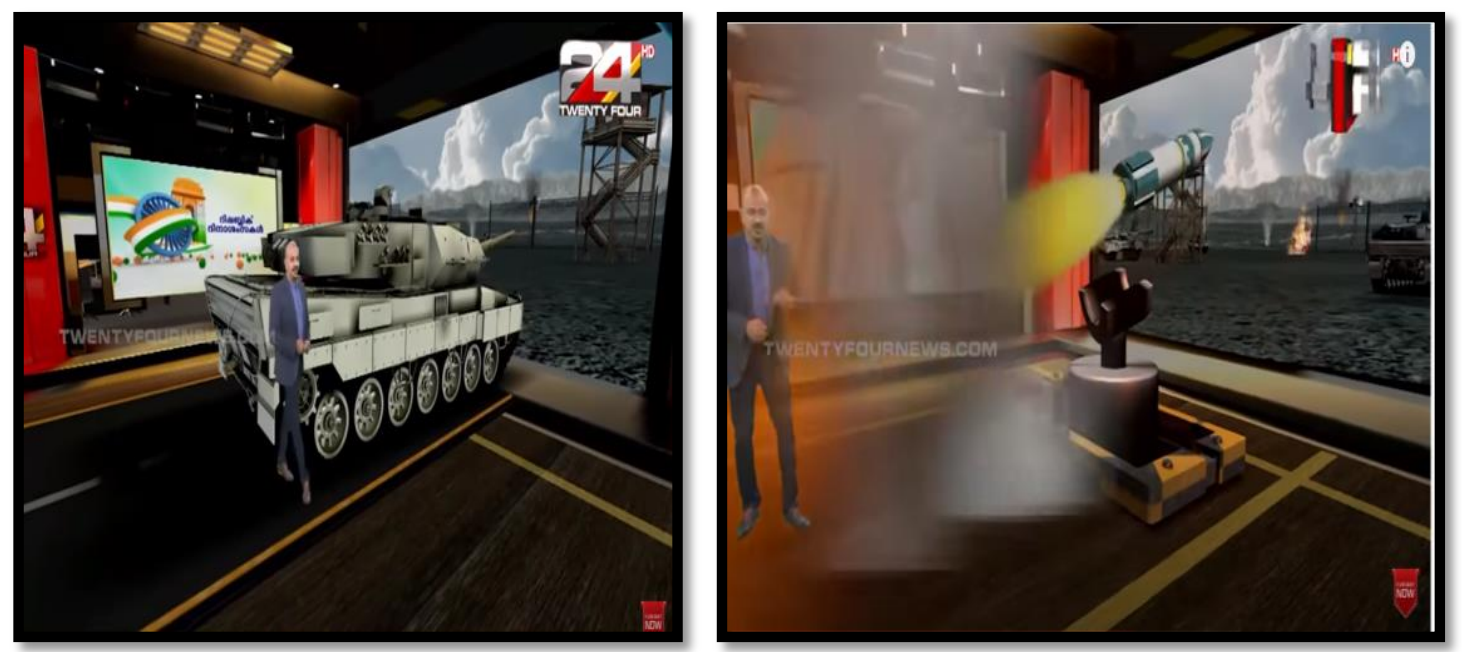

Resim 1 ve 2- Hint televizyon kanalı TV24'(Twentyfournews) de artırılmıș gerçeklik stüdyosunda sunulan savaş haberleri Kaynak: augmented reality/24 News, 2018; augmented reality/24 News, 2019
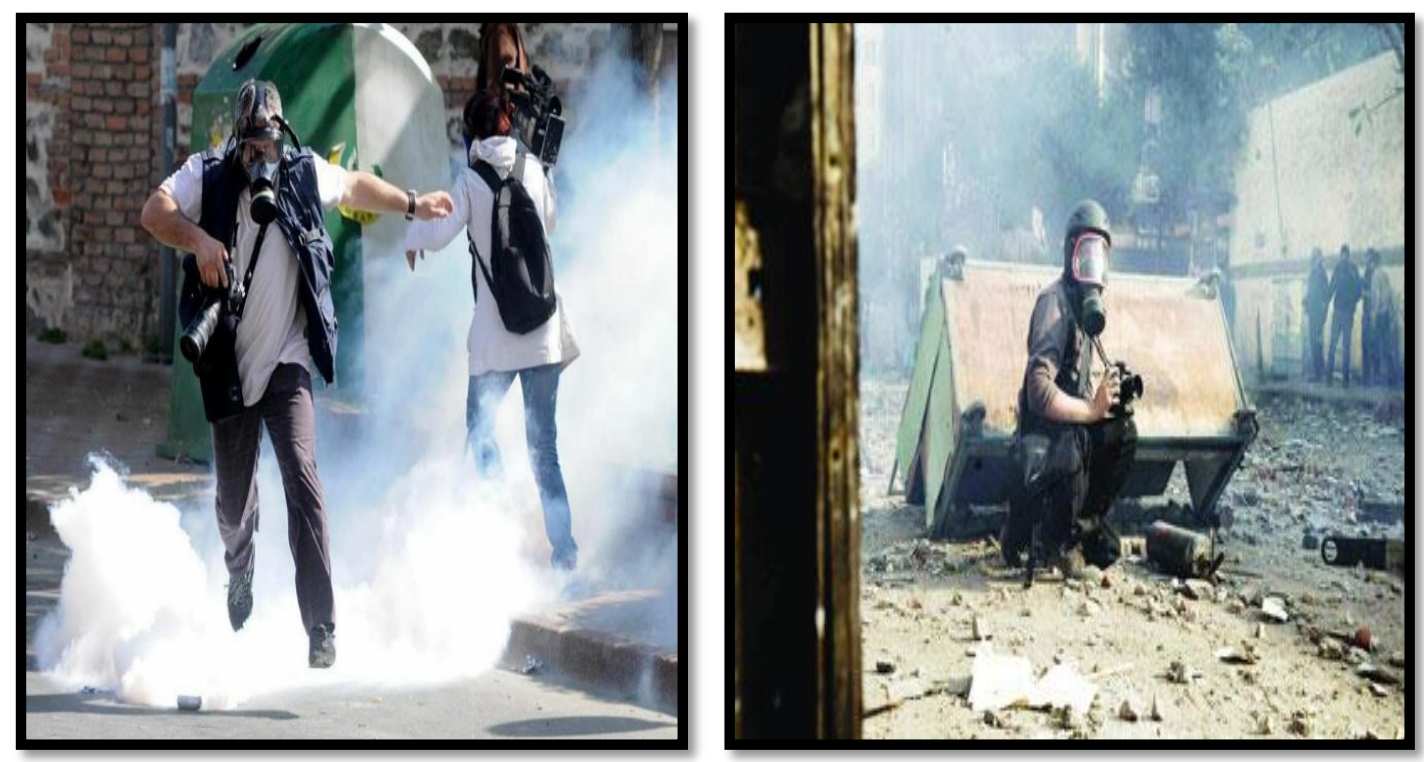

Resim 3- 1 Mayıs kutlamalarında çıkan çatıșmanın ortasında kalan gazeteciler (ensonhaber.com, 2018).

Resim 4- Suriye'deki savaşta görev yapan gazeteci (dunyabulteni.net, 2012). 
Tablo 1- Artırılmıș Gerçeklik Stüdyolarında Cekilmiș Haberlerin Analizi

\begin{tabular}{|c|c|c|c|c|}
\hline $\begin{array}{l}\text { Haberin } \\
\text { Yayınlandığ1 } \\
\text { Medya }\end{array}$ & $\begin{array}{l}\text { Haberin } \\
\text { Yayınlandiğ1 } \\
\text { Ülke }\end{array}$ & $\begin{array}{l}\text { Yayınlanan } \\
\text { Haber } \\
\text { İçeriği }\end{array}$ & $\begin{array}{l}\text { Haberde } \\
\text { Kullanılan } \\
\text { Ses } \\
\text { Efektleri } \\
\end{array}$ & $\begin{array}{l}\text { Sunucunun Haberi } \\
\text { Aktarma Biçimi }\end{array}$ \\
\hline TGRT-2017 & Türkiye & $\begin{array}{l}\text { Haberde Türk askerinin El- } \\
\text { Bab’ta göstermiş olduğu } \\
\text { başarılardan bahsedilmektedir }\end{array}$ & $\begin{array}{l}\text { Bomba sesi, } \\
\text { Uçak sesi, } \\
\text { Tank sesi. }\end{array}$ & $\begin{array}{l}\text { Haber sunucusu uçak geçerken, tank } \\
\text { gelirken kenara çekiliyor, bomba } \\
\text { atılmasıyla korkuyla kenara kaçıyor, } \\
\text { öksürüyor ve üzerine gelen tozları } \\
\text { elleriyle temizliyor. }\end{array}$ \\
\hline $\begin{array}{l}24 \text { News- } \\
2019\end{array}$ & Hindistan & $\begin{array}{l}\text { Haberde iki ülke arasında çıkan } \\
\text { çatışmalardan bahsedilmektedir. }\end{array}$ & $\begin{array}{l}\text { Bomba sesi, } \\
\text { Uçak sesi, } \\
\text { Tank sesi. }\end{array}$ & $\begin{array}{l}\text { Stüdyoda artırılmış gerçeklik teknolojisi } \\
\text { ile tank, helikopter ve uçak vardır. } \\
\text { Düşen bombaya sunucu sanki o } \\
\text { mekândaymış gibi davranarak tepki } \\
\text { vermektedir. }\end{array}$ \\
\hline $\begin{array}{l}24 \text { News- } \\
2019\end{array}$ & Hindistan & $\begin{array}{c}\text { Haber bülteninde Hindistan'ın } \\
\text { sahip olduğu silah } \\
\text { sistemlerinden } \\
\text { bahsedilmektedir. }\end{array}$ & $\begin{array}{l}\text { Uçak sesi, } \\
\text { Tank sesi, } \\
\text { Füze sesi, }\end{array}$ & $\begin{array}{c}\text { Stüdyoya tank, uçak, roket gibi cisimler } \\
\text { gelmektedir ve sunucu bu haberlerde } \\
\text { etkindir. }\end{array}$ \\
\hline
\end{tabular}

Kaynak: augmented reality/24 News, 2018; augmented reality/24 News, 2019; TGRT, 2017.

\section{Metodoloji}

İzler kitlenin, artırılmış gerçeklik uygulamalarıyla sunulan savaş ve çatışma haberlerini anlamlandırma sürecini analiz eden bu çalsşma, giriş ve özet bölümlerinde de ifade edildiği gibi savaş ve çatışma ortamlarına bilfiil tanıklık eden profesyonel savaş muhabirlerinin ve savaş ortamlarının tanıklığını yapmış iletişim uzmanlarının görüşleri üzerinden temellendirilmiştir. Çalışma kapsamında, savaş ve çatışma haberciliği konusunda uzman 4 gazeteci, bir veri gazetecisi, bir okur temsilcisi (ombudsman), bir haber sunucusu ve iki iletişim akademisyeni ile yüz yüze görüşme yapılmıştır.

Katılımcılarla olan görüşmelerde öncelikle yukarıdaki tabloda da yer alan örnek haber videoları seyrettirilmiştir. Görüşmelerde odak noktaya haber stüdyolarında savaş ve çatışma haberlerinin artırlmış gerçeklik uygulamalanı ile sunulması alınmış ve her katılımcının bireysel yaklaşımı, bakış açısı ve deneyiminin esas alınması hedeflendiğinden açık uçlu sorular tercih edilmiştir. Katılımcılara yöneltilen sorularla; artırılmış gerçeklik uygulamalarının habercilikteki kullanımı üzerine düşünceleri, bu teknolojinin savaş ve çatışma haberlerinin sunumu esnasında izler kitle üzerinde yaratacağı düşünce ve duygular, bu uygulamaların haberciliğin etik kaygılarına uygunluğu ve haberin gerçekliğini etkileyip/etkilemediği, kamuoyunun demokratik hak ve taleplerinin karşıllğı olan bilgi edinme hakkını karşılayıp/karşılamadığı, bu yöntemin her haber türü için kullanılıp/kullanılamayacağının araştırılması hedeflenmiştir. Yüz yüze yapılan görüşmeler sonucu elde edilen ses ve görüntü kayıtları yazıya geçirilmiş, aynı doğrultuda olan görüşler ise tasniflenerek aktarılmıştır.

\section{Bulgular}

ABD'nin Irak'1 işgaline gazeteci olarak savaşa tanıklık eden savaş muhabiri Mete Çubukçu, savaşla birlikte medya ve siyaset çalışmalarında sıkça anılan CNN haber kanalının savaş alanından yaptığı yayınlarla dış politikayı dönüştürme gücüne atfen kullanılan "CNN efekti” (Gilboa, 2005) kavramını şöyle tanımlamaktadır:

CNN efekti dediğimiz şey; aslında bu bir savaş değildi. Savaş diye bir şey seyrettirildi. İlk defa canlı yayında an ve an izletildi. Bu normalleştirildi. Bir yerler bombalanıyor, yıkılıyor, füzeleniyor ve bunlar canlı yayında izlettiriliyor. Artık sanki insanların olmadığı makinelerin, teknolojik aletlerin birbirleriyle savaştı̆g bir sanal dünya hissi yaratıllyor. Aslında o çatışma bölgelerinde hem kendi taraflarından hem de diğer taraftan insanlar ölüyor; hastaneler, karakollar, camiiler, kiliseler yıkılıyor. Savaş sanal bir şey değildir, savaş korkunç bir gerçektir (Mete Çubukçu, kişisel görüşme, 15 Şubat 2021).

Eski bir asker olan ve savaş bölgelerinin yakından tanıklığını yapan akademisyen Mustafa Sadakaoğlu savaşın şiddetten uzaklaştırılarak, estetize edilen yüzünü anlatır:

Cervantes, Donkişot'un ağzından savaşı tanımlarken şöyle diyor: Savaş neşeli bir şeydir. Işııklı bir günde ortaya çıkar taraflar. Ve centilmence savaşırlar. Bunu okuduğunuz zaman orta çağın o uzun kılıçlı, 
uzun mızraklı şövalye savaşlarını adeta bir polo oyunu gibi centilmence yapılan bir spor müsabakası gibi algılarız. Oysa gerçek bu değil. Hayır, savaşta insanların kolları, bacakları kopar. İnsanlar vahşi bir şekilde karınları deşilerek öldürülür. Sonra biz savaşın düz ara şiddetini 'Batı Cephesi’nde bir şey yok' da görürüz. Orada anneye yazılan mektupta şöyle der: 'Anneme sakın burada siperlerde gaz bombası atıldıktan sonra insanların nasıl öldügünü anlatmayın. Yüzleri mosmor, vücutları kaskatı diye’. Savaş dediğimiz düz ara budur. Biz savaşı, şiddeti teknolojinin gelişmesiyle beraber; 1991 yllında Körfez Savaşı'nı Peter Arnett’in ünlü Bağdat’taki otelin çatısından yaptı̆̆ '4 Temmuz törenleri gibi ne kadar güzel havai fişekler gibi' diyerek tanımladığı uçan Tomahawk füzeleri üzerinden estetize ettik. Hâlbuki o füzeler düştüğü yerde yaklaşık 20-25 metre çapında krater oluşturuyor. İnsanları paramparça ediyor. Kaldı ki arka arkaya 1şık hızıyla akan bir saldırıdan bahsediliyor. Biz Bağdat'nn uğradığ şiddeti burada net bir şekilde kavrayamıyoruz (Mustafa Sadakaoğlu, kişisel görüşme, 16 Şubat 2021).

Çalsşmanın kaynak kişileri olan, dünyada birçok cephede savaşa tanıklık etmiş profesyonel savaş muhabirleri yapılan derinlemesine mülakatlarda; artırlmış gerçeklik teknolojisi ile sunulan savaş/çatışma haberlerinin seyirlik gösterilere dönüştürüldüğünü belirtmektedirler:

Artırılmış gerçeklik teknolojisi ile sunulan haberlerde; tank geliyor, spiker üzerini temizliyor. Yukarıdan bombalar atıliyor. Spiker tozdan öksürüyor. Bu kurgusal bir ortam, gerçeklikten uzak. Bu kabul edilemez bir şey. Stüdyoda olmayan insanı hologramla stüdyoya sokmak gibi bir durum. Gerçeklik bağlamından koparılliyor. Haberle bağdaşan bir şey değil. Haber, saf gerçeklik üzerine oluşturulması gereken bir metindir. Bu durum demokratik toplumlar açısından çok ciddi riskler barındıran bir durum. Ben tamamen buna karşıyım, bunun yapılmaması gerekir. Haberde kurgusal bir dünya yaratılamaz, gerçeklik bağlamından koparılamaz. Çünkü haber gerçeğin birebir gösterimi üzerine kurulan bir metin, bir anlatımdır. Bilgiyi kirletmeye hakkımız yoktur (Engin Başçı, kişisel görüşme, 18 Şubat 2021).

Afganistan, Irak, Filistin, İsrail, Bosna, Kosova vb. gibi savaş/ kriz bölgelerinde muhabirlik yapan Mete Çubukçu da bu minvalde düşünmektedir:

Savaş bölgeleri ciddi alanlardır. Gazeteciler reel bir iş yapıyor, zorlu ve o anı yaşıyor, yaralanıyor, kaçmak zorunda kalıyor hatta bazen maalesef hayatını kaybediyor. Stüdyoya gelince, bunlar şov tabii ki seyircinin ilgisini çekmeyi amaçlıyor ama tersten baktığımızda savaşın gerçeklikten uzaklaştı̆̆ını görüyoruz. Zaten yeni kuşaklar dünyayı teknolojik olanaklarla daha dışarıdan izliyor. Bunun sonucunda bunun bir sanal oyun olduğunu saniyor ama savaşta sanal yoktur, savaş gerçektir (Mete Çubukçu, kişisel görüşme, 15 Şubat 2021).

Kuzey Irak, Afganistan, Lübnan, Çad, Filipinler, Kuzey İlanda, Orta Amerika, Afrika’da savaş ve çatışmalara gazeteci olarak tanıklık eden savaş muhabiri Coşkun Aral:

Reyting televizyon için reklam girdilerinin artışı demek, reyting yüzünden yapıllyor bunlar ancak ben bunları ciddiye almıyorum ama tabii savaşın çok ciddi bir iş olduğunu söylemem gerekir, demektedir (Coşkun Aral, kişisel görüşme, 18 Şubat 2021).

Afganistan, Rusya-Gürcistan, Libya, Suriye gibi bölgelerdeki savaşlara ve Mısır'daki darbe girişimine tanıklık eden savaş muhabiri Cem Tekel, savaşın artırılmış gerçeklik stüdyolarında sunucunun görüntülere eşlik eden vücut devinimleri ile bir şov ortamına dönüştürülemeyeceğini vurgular:

Kaçırılma riski yaşadık, yanımıza havan düştü, üzerimizden mermi geçti kısaca birçok tehlike atlattık. Biz haberlerimizde parçalanan hayatları, ölen insanları, zarar gören çocukları yerle bir olan şehirleri kamuoyuna göstermeye çalışıyoruz. Savaşta silahlar, toplar, tüfekler değil, savaşın ortasında kalan insan önemli. Savaşı en iyi onlar anlatır. Savaş bir şov ortamı değil acı veren gerçektir. Amaç insanların yaşadıkları acıları ve zorlukları dünya kamuoyuna anlatmaktır. İnsanların acılarının sesi olur haberci. Amaç o gün haberi nasıl seyrettiririm demek değildir (Cem Tekel, kişisel görüşme, 20 Şubat 2021).

Bosna, Kosova, Sırbistan, Karadağ, Makedonya, Çeçenistan, Somali, Cezayir, Irak gibi bölgelerde savaş muhabiri olarak çalışan gazeteci Şerif Turgut savaşın normalleştirilmesinden, artırılmış gerçekliğin duygular üzerindeki etkisinden bahseder:

Körfez Harbi'nde yaşanan belki ilk olduğundan zihinlerimize kazındı. Ne yazık ki artık bütün savaşlar böyle. Savaşları bir film izletir gibi izlettirerek, alıştırdılar. Anormalin normalleşmesine başta karşı çıkmak gerekiyordu. Bir kez kabul ettirdiklerinde arkası işte böyle geliyor. Maalesef insanlar başkalarının acılarına o kadar duyarlı değiller hatta öyle ki bir savaşın gerçeğini anlat sıkılır ama iyi bir savaş filminde ağlayabilirler. 
Artırılmış gerçeklikle sunulan bu haberler duyguları daha da öldürür, gerçekten uzaklaştırır (Şerif Turgut, kişisel görüşme, 19 Şubat 2021).

Uzun yıllar boyunca medya ombudsmanllğı (okur temsilciliği) yapmış, izler/okur kitle ile yayın sürecini yönetenler arasında köprü görevinde bulunarak etik ihlalleri üzerine yazılar yazmış, Dünya Ombudsmanlar Birliği'ne üye gazeteci Faruk Bildirici, artırılmış gerçeklik teknolojisi ile yapılan savaş/çatışma haberlerindeki gazetecinin rolünü etik kriterler üzerinden değerlendirir:

Arttırılmış gerçeklik teknolojisinin kullanılması gazetecilik için bir avantaj. Ama bunu nasıl kullandığınız önemli. Mesele bunu nasıl verdiğiniz. TGRT" nin o görüntülerinde tam bir savaş çı̆̆ırtkanlığı vardı. Dünyanın her tarafinda gazeteci dediğin savaşa karşı çıkar, barıştan yana olur. Militarist bir yaklaşım sergilemez. TGRT' de öyle bir yaklaşım vardı. Tamamen militarist, savaşın yanında, savaşı destekleyen bir yaklaşım. Şöyle savaşı destekleyen bir gazeteci, kendi ülkesine zarar verir. Hem savaşlar kötüdür. İnsanların ölümüne yol açar daha da ötesi biraz dişardan bakarsan eleştirebilirsin, içerden bakarsan eleştiremezsin. Eleştiremezsen de kendi ülkene zarar veririsin. Biz gazeteciler eleştirerek hataların düzelmesini sağlanı. Yoksa hatalar düzelmez (Faruk Bildirici, kişisel görüşme, 20 Şubat 2021).

Gazeteci akademisyen Engin Başçı bu teknolojiyle yapılmış bir savaş/çatışma haber sunumunun habercilikte etik ihlallerine neden olabileceğini belirtmektedir:

Sanal gerçeklik ve artırlmış gerçeklik terimleri gerçekliğin yeniden üretimiyle ya da bozulması ve etkisinin artırlması meselesiyle karşılık gelen bir şey. Sen gerçekliği artırarak nasıl sunarsın, zaten görüntü gerçekliği bozan bir şey zira ikinci bir el. Üstüne üstlük zaten bozulmuş halinin bozulmuş hali gibi. Habercinin müthiş bir sorumluluk duygusuyla ve gerçeğe olan bağlliğıyla hareket etmesi gerekir. Orada olup biteni çarpıtma hakkı yoktur. Çok nesnel hareket etmesi gerekiyor. Gazeteci kimliğinin ve mesleğin ona yüklediği meslek ilkelerini göz önünde bulundurmak zorundadır. Savaş korkunç bir şeydir, kimsenin kutsamaması gerekir. $\mathrm{O}$ anlamda orada yaşayan insanların dramını anlatabilmek, oradaki gerçekliğin anlaşılabilmesini sağlayabilmek açısından nesnellik çok önemlidir (Engin Başçı, kişisel görüşme, 18 Şubat 2021).

Günümüzde bilginin akışı hızlıdır, kısa sürede doğar ve ölür. Bu yüzden de bilgi giderek hafifleyen bir olgu haline gelmektedir. Başçı haberin içeriğinin çabuk tüketilmesinin haricinde, hızlı kurgunun da gerçeği deforme ettiğini belirtmektedir:

Hız genel olarak bizi gerçeklikten koparan bir şey. Biz bunu hem kendi yaşam deneyimimizden biliyoruz hem de günlük hayatımızdan. Ne kadar çok hızlanırsak o kadar gelgeç, o kadar sıradan, o kadar yerle temasımızı kaybeden ilişki pratiği içinde günümüz geçiyor. Hızlı kurgu da bizi gerçeklikten kopartıyor. Ne kadar efekt ne kadar hız eklerseniz o kadar gerçeği bozarsınız. Ben de 1991 yılında uçan toma füzelerini gerçekten basit zannediyordum ancak onların düştüğü yerlerdeki tahribatı gördüğüm zaman yanıldığımı anladım, birçok insan bu bilgiden yoksun kaldığı için savaşı da böyle algı1lıor. Akşam yemeği tüketir gibi savaş da tüketiliyor (Engin Başçı, kişisel görüşme, 18 Şubat 2021).

Sadakaoğlu da hızın bilişsel süreç üzerindeki negatif etkisinden bahsetmektedir:

Haberi hızlandırmak haberin içeriğini boşaltmaktır. Gerçeği 'distort' (çarpıtmak) etmektir. İzleyiciye sunulan görüntü yeniden üretilmiş bir gerçekliktir artık. İnsan, söz gelimi uçakla yani hızla giderken yolculuğu deneyimleme yeteneğini kaybeder. Bu tarz haberler de izleyiciye savaşın şiddetini görmekten alıkoyuyor. Propaganda filmlerinde de hızlı geçişler vardır. Sözüm ona izleyiciye bağlantı kurma ve metne dâhil olma imkânı sunar ama tam tersine izleyiciyi istendiği şekilde yönlendirmeye yarar bütün bunlar (Mustafa Sadakaoğlu, kişisel görüşme, 16 Şubat 2021).

Haber hikâyesini anlatan stüdyodaki sunucu, bu yeni teknolojilerle haberi aktarmak, gerçeğin sunumunu yapmak yerine gösterinin bir parçası haline gelmektedir. Gerçek bir dönüşüm geçirirken, haberin sunucusu da sunucunun bedeni de bu yeni dönüşümün parçası olur. Haber sunucusu Mehmet Derindağ, artırılmış gerçeklik stüdyolarındaki sunumun teknik olarak nasıl yapıldığını şöyle açıklar:

Sunucunun nasıl yönlendirildiğine gelince, yönetmen spikeri uyarır 'arkadan uçak gelecek sen görüntüye göre hareket et' diyerek. Yönetmenle istişare halindesin, mesela kösşeye yürü, şöyle işaret et gibi. Yönetmen size önceden görüntüyü izletir ve ona göre hareket edersin. Ama bunu canlı yayında yapmak daha zordur (Mehmet Derindağ, kişisel görüşme, 18 Şubat 2021).

Derindağ, televizyon stüdyosundaki bu sunumun haberin içeriğini yok ettiğini belirtmektedir: 
Ben görüntünün tamamen haberin önüne geçtiğini, anlatılan haberin ikinci plana düştüğünü düşünüyorum. İzleyicilerin zaten stüdyonun içindeki görüntülerden gerek masa gerek kadın spikerin saç1kıyafeti-takısı vb. şeylerden dolayı dikkati dağıllyor. Bir de o gerçeklik boyutunu koyduğumuz zaman, olaya daha abartılı yaklaşılıyor. Zaten haber her şeyi anlatıyor. Daha önce de müzik kullanıllyordu haberde ve o bile haberin nesnelliğini bozuyordu. Sonra müziği kaldırdılar Haber daha objektif bir form kazandı. Haber orada apaçı kendini belli ediyor başka bir anlatıya ne gerek var. Daha önce Rusya yapmıştı; stüdyoya uçaklar girdi, tanklar girdi patladı, yani teknoloji tamamen haberin önüne geçti, haberi şova dönüştürdü. Şimdi sorsak "O haber neydi?" diye kimse cevap veremez. Akılda kalan tek şey stüdyoya bir uçak girmesi, tank girmesi, top patlamasıdır (Mehmet Derindağ, kişisel görüşme, 18 Şubat 2021).

BBC artırlmış gerçeklik teknolojisinin dikkatli kullanılmasından yana. Ruslar çok kullanıyor, Amerikalılar görsel anlamda kullanıyor. Zaten Rusya'da haberciliğin durumu vahim. Örneğin CNN International hologram tekniğini kullandı ve dünyaya pazarladı. Avrupa televizyonlarında, Türkiye'de de denendi. Ancak bu durum habere uymuyor. Başka bir stüdyodaki sunucuyu stüdyoda karşllklı konuşuyorlarmış gibi gösteriyorlar. Işınlama dediler buna. Bu tabii gerçeklik yanılsaması üzerine, gerçeğin yeniden kurmacasal bir şeklidir. Orada haber yoktur yani. Haber burada bozulur ve kirlenir (Engin Başç1, kişisel görüşme, 18 Şubat 2021).

Teknoloji ile iç içe geçmiş, yeni bir alan olan veri gazeteciliğinde uzman isim Pınar Dağ, bu teknolojinin haberde farklı konularda anlatımı desteklemek açısından kullanılmasının avantajları olabileceğini aktarmaktadır:

$\mathrm{Bu}$ sunumlarda abartı var, bunlara gerek yok. Ancak bu uygulamaların iklim meseleleri gibi konularda etkin kullanılabileceğini düşünüyorum. Örneğin bir dalganın büyüklüğünü ve hacmini bir binayla ölçme ve kıyaslama; ne kadar yıkıcı olabileceğini anlama şansınız olabiliyor. Güçlü bir binayı yıkma hızını size anlatıyor. Siz ekranda çok rahat bir şekilde tsunami tehlikesinde ne kadar yükseklikteyseniz kurtulursunuz onu görme şansınız oluyor. Çok hızlı bir şekilde izleyiciye mesaj vermiş oluyorsunuz. Ama savaşta bunu izlemek ben de küçük çaplı travma yaratır. Savaș bölgesine gitmiș gibi orada bir amaçtan sapmıș oluyorsunuz. Oradaki ölümleri anlatmanız gerekirken, biz böyle tanklarla girildi diye anlatıyoruz. Olayı amacından saptırır hale getiriyoruz. Kamu adına yapılan çalısmada haber şova dönüştürülüyor (Pınar Dağ, kişisel görüşme, 21 Şubat 2021).

Mehmet Derindağ savaş/çatışma/askeri operasyon gibi kriz ortamlarında kullanılmasını sakıncalı bulduğu bu teknolojinin farklı habercilik türlerinde kullanılabileceğini belirtmektedir:

Hava durumunda bu teknolojiyi kullanmak çok güzel bir görüntü yaratabilir, örneğin içeri kar yağması, ya da yağmur yağması gibi (Mehmet Derindağ, kişisel görüşme, 18 Şubat 2021).

Engin Başçı da aynı minvalde bazı haberlerde görselliğin izler kitlenin kafasında somutlaşabilmesi için artırılmış gerçeklik teknolojisi kullanımının avantajlı olabileceğini belirtmektedir:

Düz haberde artırllmış gerçeklikten bir grafik hizmeti olarak yararlanılabilir. Burada görüntünün el vermediği durumlarda mesela depremle ilgili bir haber yapıyorsunuz, fay hatlarının durumunu anlatıyorsunuz, burada artırılmış gerçeklik, sanal gerçeklik uygulamalarından haberin anlaşılırlığını artırmak, görsel etkiyi artırmak için yararlanılır. Özetle çok özel durumlarda, çok özel amaçla görüntü eksikliğini gidermek ve haberdeki durumu anlaşılır hale getirebilmek açısından sinırlı olarak kullanılmasından yanayım (Engin Başç1, kişisel görüşme, 18 Şubat 2021).

\section{Sonuç}

Görselin insanoğlunun varoluşundan beri önemli bir yeri olsa da duyularımız arasında ön plana çıkması aydınlanma çağıyla birlikte olmuştur. Günümüzde göz gerçeğin tanığı, anlam üretiminin odak noktası haline gelmiştir/getirilmiştir. 19. yüzyıldan itibaren izleyiciye dönüşen bireyle, görme duyusu, görüntü gibi kavramlar ön plana çıarken, demokratik toplumlarda kamuoyunu bilgilendirmekle görevli basın da bu sürece paralel olarak bir dönüşüm yaşamıştır. Ancak hız, kurgu, teknoloji unsurlarıyla görselin egemenliğine bırakılan, kültür endüstrisinin bir ürünü haline getirilen, magazinleşen haberle birey de yaşadığı dünyaya yabancılaşmaya başlamıştır. Bir benzetme yaparsak, Lacan'ın “ayna felsefesi' nde bireyin ömür boyu kendini tamamlayacak imgenin peşinden koşması gibi, birey teknolojiyle kendisine sunulan 
sembollerin baş döndürücü çarkına kendini bırakıp, körelttiği düşünsel yetiyi arar gibidir, ancak ona kavuşamaz.

İzler kitleye, haberdeki ortamı deneyimleme imkânı vermek amacıyla yola çıkan televizyon stüdyolarındaki artırılmış gerçeklik teknolojisi ile savaş, hava durumu, deprem, spor, kaza vb. gibi haberler sunulmaktadır. Araştırmadan elde edilen bulgulara göre; bu teknoloji ile gerçeğe daha yaklaştırılmaya çalıştırılan savaş ve çatışma haberlerinin, tam aksine nesnellikten koparıldığı, "gerçek" bağlamından uzaklaştırıldığı tespit edilmiştir.

Bu çalısmada artırılmış gerçeklik teknolojisiyle üretilen temsillerin nasıl alımlandığı savaş ve çatışma haberciliği üzerinde uzmanlaşmış gazetecilere sorulmuştur. Araştırma bulgularına göre; bu teknolojiyle sunulan savaş ve çatışma haberlerinde sunucunun bedenini de çatışmanın içine sokması onunla hareket ediyormuş gibi oradaymış izlenimi uyandırması bireyi düşünceden, dünyayı algılamaktan, hissetmekten uzaklaştırmaktadır. Haberin sunumundaki imgelerin hızlı döngüsünde, bedenin yeniden anlamlandırıldığı ölüm algisından uzak bir yapı inşa edilmektedir. Stüdyodaki sunucunun görselle birlikte sergilediği hareket devinimlerinde bedenin ölümsüzlügü algısı seyirciye aktarılır. Oysa kriz ortamlarını bilfiil yaşayan savaş muhabirleri savaşın, içinde ölümü barındıran ciddi bir iș olduğunu vurgulamaktadır.

Artırılmış gerçeklik uygulamalarıyla televizyon stüdyolarında teatral bir oyuna dönüștürülen savaș/çatışma haberlerinin yok edilmiş bir gerçeklikten öteye gidemediği; haber sunumunda yer alan alegorik gösterideki hız nedeniyle imgelere yakınlaştığını sanan seyircinin aslında kendi özsel gerçekliğinden, dünyanın gerçekliğinden koptuğu, katılımcılar tarafından ifade edilmiştir.

Haber sunumundaki bu gösteri, kapitalizmin önerdiği gibi bireyin mutlak varlığını sürdürmesine odaklanır. Zira birey ölüme sadece seyircidir, ölüm olsa olsa ancak bir başkasının makûs kaderi olabilir. Bundan ötürü, sunucu anlatının sahnesinde yer alırken, haberin öyküsü önemini yitirir sahne ön plana çıkar. Sinemasal mizansen savaşın gerçeğini bertaraf eder.

$\mathrm{Bu}$ amaçla televizyon, artırılmış gerçeklik anlatısıyla bir film gibi, dünyayı bir sahne gibi kullanırken, izleyiciye haberi magazinleștirmekte, gerçeklik bağlamından koparılmaktadır. Oysa savaşın gerçeğini bazen tek bir kare fotoğraf anlatır: Halepçe Katliamı'nı Ramazan Öztürk'ün "Sessiz Tanık” isimli fotoğrafinın tüm dünyaya anlatması, Suriye'deki iç savaștan kaçan mültecilerin Muğla'dan Yunanistan'a geçerken botlarının batmasıyla hayatını kaybeden Aylan bebeğin kıyıya vuran ölü bedeninin yansıdığı fotoğraf karesinin göçmenlerin dramını tüm dünyaya göstermesi gibi. Çalışmada haberin en önemli unsuru gerçeklik' in sansasyonel haber yapmak adına bağlamından koparıldığı görüşü katılımcıların ortak kaygısı olarak tespit edilmiştir.

Haberler, günlük hayatta anlam inşa eden temsillerdir. Ancak televizyon izleyicileri artırllmış gerçeklik teknolojisi ile yapılmış haberleri seyirlik bir gösteri, bir oyun gibi izlemektedir. İzleyicinin "bilgilendirici, yansıtıc1, aydınlatıcı" gibi özelliklerle tanımladığı haber yerini; "duygusal, çarpıcı, eğlendirici, kolay anlaşılır, çabuk unutulur, sıkıcılıktan ve ciddiyetten uzak" bir hale bırakmaktadır. Dolayısıyla araştırmanın temel sorunsalı olan kritik haberlerin bu teatral sunumunun, kamuoyunun hak ve taleplerini karşlayacak "bilgi edinme hakkı"nı zedelediği görüşüne varılmıştır.

Çalışmadan elde edilen bulgulardan yola çıkarak, Türkiye'de televizyon haberciliğinde sayısal teknolojiler temel alınarak basın meslek ilkelerinin düzenlenmesi gereklidir. Savaş ve çatışma gibi insanlığa yıkıcı etkisi olan haber alanlarında artırlmış gerçeklik teknolojisinin kullanılması sorunlu bir alan yaratmakla birlikte; tüm katılımcıların ortak görüşü: anlaşılması zor bir konuyu ya da soyut bir kavramı kamuoyuna daha iyi anlatabilmek/kavratabilmek adına; spor, hava durumu, depremle ilgili bilimsel detaylar, seçimlerin grafiksel anlatısı gibi başka haber türlerinde -etik ihlallere sebebiyet vermeden- bu teknolojinin gerektiğinde kullanılabileceği tüm katılımcıların ortak görüşü olarak tanımlanmıştır.

Artırllmış gerçeklik teknolojisi ile sunulan savaş ve çatışma haberlerinin izler kitle üzerindeki etkilerini iletişim profesyonellerinin gözüyle analiz eden bu çalışmanın, ileride ikinci bir adım olarak izleyiciler üzerinden de yapılması muhakkak ki araştırma konusunu daha derinlikli bir alana taşıyabilir.

\section{Extended Abstract}

The discussion of the "body-mind duality" problematic that was first noticed in the age of enlightenment continues to this day. When sight was attributed as a greater sense, the saying "truth can 
only be seen" gained greater importance in daily life. Today, with the information technologies which give a greater emphasis on vision, each new tool put forward forms new connections between the body, time, place and perception. In the field of journalism, with the utilisation of new technologies, different ways of expression are being used.

In the last few years, especially in Turkey where media ownership as drastically changed, news reports have gotten more and more tabloid-like in their presentation. Television news have been dramatized with the use of music, various audio and visual effects and faster editing. Television news have been presented to the viewer as a mix of entertainment and information referred to as "Info-tainment". With the Age of Enlightenment, two different opinions have formed in response to the growing importance of the "visual". While some thinkers have defended the idea that visuals improve the cognitive process, others thinkers have said that instead of improving, it weakens the cognitive process especially when used in media. According to these thinkers, the human has begun to see but not perceive all which happens around him on account of losing the ability to question and to interpret what he sees. Giovanni Sartori has said that the "homo sapiens" have transformed into the "homo-videns".

Augmented reality being one of these newly developed technologies is used to give the viewer a sense of actually being there. Because of this, traditional storytelling is getting weaker but storyliving is gaining more importance. The subject of this study is: "Is the use of augmented reality in forming a more theatrical approach to journalism who has a heavy role in objectively informing the public a good practice for journalism?". For this analysis, four experienced conflict journalists, a data journalist, an ombudsman, a television news reporter and 2 academics one of which has a military background and the other a journalistic one have been interviewed. The hypothesis of this study is that the use of augmented reality in news cowering wars and conflicts distracts the viewer from reality. In line with this, the people interviewed have been shown 3 news broadcasts, two of which have aired on Indian news channel Tv24 News and the third one aired on the Turkish news channel TGRT, and were asked to give their opinion. According to the obtained findings of this study, the viewer loses contact with reality due to the fabricated nature of the news broadcast including such elements like the news reporter acting as if he was in the hot zone of the conflict with the aid of augmented reality. The sense of death that is apparent in reality is not conveyed to the viewer.In contrast, conflict reporters who have experienced these situations first hand have expressed in interviews the seriousness of war and its consequences including death. Because of this, augmented reality technology in place of presenting reality, replaces it with a fake one. It shall not be forgotten that there is more than one way of reporting on matters such as war or conflict. We can conclude that the theatrical mise-en-scene in these kinds of news reports distorts reality and does more harm than good but it might prove beneficial to use in informing the public in areas such as sports, weather broadcasts and election results. Journalism ethical practices must be restructured with digital technologies in mind.

Keywords: Augmented Reality, Television, Conflict News, War News, News Studios, Storyliving, Storytelling

\section{Kaynakça}

Aral, C. (2021). N. B. Ekşioğlu Sarllar tarafindan gerçekleştirilen röportaj.

Azuma, R. T. (1997). A survey of angmented reality. Presence, 6(4), (pp. 355-385).

Barthes, R. (2001). Rhetoric of the Image. J. in Evans and S. Hall (Eds.), Visual Culture: The Reader (pp.4041), Sage Pub.

Başç1, E. (2021). N.B. Ekşioğlu Sarılar tarafindan gerçekleştirilen röportaj.

Baudrillard, J. (2019). Sessiz Yiğnlarn Gölgesinde Toplumsalın Sonu. O. Adanır (Çev.), Ankara: Doğu Batı Yayınlan.

Bildirici , F. (2021). N. B. Ekşioğlu Sarılar tarafindan gerçekleştirilen röportaj.

Bowdon, B. T. (2018). 50 Felsefe Klasiği- Düsünmek, Varolmak, Eylemde bulunmak, Görmek (s. 19), İstanbul: Pegasus Yayınları.

Çubukçu, M. (2021). N.B. Ekşioğlu Sarılar tarafindan gerçekleştirilen röportaj.

Dağ, P. (2021). N. B. Ekşioğlu Sarılar tarafindan gerçekleştirilen röportaj. 
Debord, G. (1996). Gösteri Toplumu. A. Ekmekçi (Çev.) (ss.97-131), İstanbul: Ayrıntı Yayınları.

Derindağ, M. (2021). N. B. Ekş̧ioğlu Sarılar tarafindan gerçekleştirilen röportaj.

Ergül, H. (2000). Televisyonda Haberin Magazinelleşmesi (ss. 21-103), İstanbul: İletişim Yayınları.

Florensky, P. (2001). Tersten Perspektif, Zeynep Saym'ın sunusu ile. Yeşim Tükel (Çev.), İstanbul:Metis Yayınlar1.

Ginsburg, F. D., Abu-Lughod, L., \& Larkin, B. (2002). Media Worlds, Anthropology in new terrain (s.19),

California: University of California Press.

Güngör, N. (2011). Illetişim Kuramlar Yaklassımlar. Ankara: Siyasal Kitabevi.

Jenks, C. (Ed.). (1995). Visual culture. London: Routledge.

Milgram, P. \& Kishino, F. (1994). A Taxonomy of Mixed Reality Visual Displays. IEICE Transactions on Information Systems, Vol E77-D, No.12.(p.1322).

Mitchell , W. (1995). Picture Theory. Chicago: University of Chicago Press.

Morris, J. S. (2004). The effects of dramatized political news on public opinion. The American review of politics.

(25), (pp. 231-343).

Morrison, D. (1992). Television and the GulfWar. London: John Libbey.

Oskay, Ü. (1998). Ali Kırca tarafindan gerçekleștirilen röportaj. ATV Siyaset Meydanı.

Pavlik, J., \& Bridges, F. (2013). The Emergence of Augmented Reality (AR) as a Strotelling Medium in Journalism. Journalism \& Communication Monographs (pp.4-59) doi:DOI:10.1177/1522637912470819.

Postman, N. (1985). Amusing ourselves to death: Public discourse in the age of show business. New

York: Penguin Books.

Robins, K. (1999). İmaj Görmenin Kültür ve Politikası. N. Türkoğlu (Çev.), (s. 81), İstanbul: Ayrnntı Yayınları.

Robins, K. (2013). İmaj Görmenin Kültür ve Politikası. N. Türkoğlu (Çev.), (ss.117,-118), İstanbul: Ayrıntı Yayınlar1.

Robinson, H. (2003). 'Dualism', in S. Stich and T. Warfield (ed.), The Blackwell Guide to Philosophy of Mind, Oxford: Blackwell, (pp. 85-101).

Sadakaoglu, M. C. (2020). Paul Virilio'nun Kuramsal Dünyasina Kısa Bir Giris Denemesi. International Social

Sciences Studies Journal, (e-ISSN 2587-1587) Vol 6. lssue 54, (ss. 204-214).

Sadakaoğlu, M. (2021). N. B. Ekşioğlu Sarılar tarafından gerçekleştirilen röportaj.

Sartori, G. (2004). Görmenin iktidar. G. Batuş (Çev.), (ss.24-77), İstanbul: Karakutu Yayınları.

Steurer, J. (1992). Defining Virtual Reality: Dimensions Determining Telepresence. Journal of communication, 42(4), (ss.73-93). doi:https://doi.org/10.1111/j.1460-2466.1992.tb00812.x.

Sundar, S., Kang, J. \& Danille, O. (2017). Being There in the Midst of the Story: How Immersive Journalism Affects Our Perceptions and Cognitions. Cyberpsychology, Behavior and Social Networking, 20(11), (pp. 672682).

Taylor, P. (1992). War and the Media: Propaganda and Persmasion in the Gulf War. Manchester Manchester University Press.

Tekel , C. (2021). N. B. Ekşioğlu Sarılar tarafından gerçekleştirilen röportaj.

Turgut, Ş. (2021). N. B. Ekşioğlu Sarılar tarafından gerçekleştirilen röportaj.

Virilio, P. (1998). Hız ve Politika. M. Cansever (Çev.) (s.30), İstanbul: Metis Yayınları.

White, A. (2017). Ethics in the news. London: The Ethical Journalism Network.

Yıldız, N. (2013). Aş̧ Yǚsyll Bitti, Aşk'ta Isş'te, Siyaset'te Yeni Zamanlar (s. 96), İstanbul: Doğan Kitap.

İnternet Siteleri

Arapkirli, Z. (2017). Savaşın İlk Kurbanı Gerçeklerdir. https://arsiv.ntv.com.tr/news/110341.asp,

[Erişim tarihi: 20 Kasım 2017].

Atay, T. (2021). Savaşın Pornografisi. https:gazeteyolculuk.net/savasin-pornografisi-tayfun-atay/amp, [Erişim Tarihi: 28 Ocak 2021].

Malcolm, J. (2019). Get ready to hear a lot more about 'XR'. https://www.wired.com/story/what-isxr/. [ Erişim tarihi: 10 Kasım 2020]. 
Maschio, T. (2017). Stroyliving: A Study of VR in Journalism-Traning Center. https://newslab.withgoogle.com/assets/docs/storyliving-a-study-of-vr-in- journalism.pdf, [ Erişim tarihi: 5 Ocak 2021].

Sina, A. (1996). L'urbanité virtuelle, l'être-au-monde au temps réel. https://www.erudit.org/en/journals/inter/1996-n65-inter1112074/46465ac.pdf, [ Erişim tarihi: 10 Kasim 2020].

Unutmaz, (2017). Sanal Gerçekliği Geride Bırakan Teknoloji Artırılmıș Gerçeklik. https://roboturka.com/gomulu-sistem/sanal-gercekligi-geride-birakan-teknoloji-artirilmis-gerceklik/.

[Erişim tarihi: 21 Aralık 2020].

https://www.dunyabulteni.net/images/haberler/250x190/2012/02/27/k_suriye-gazeteci.jpg, [Erişim tarihi: 11 Kasim 2020].

https://www.youtube.com/watch?v=_Idy0izevN8\&ab_channel=SanalGer $\%$ C3\%A7eklikD $\%$ C3 $\%$

BCnyas $\% C 4 \%$ B1, [Erişim tarihi: 20 Ocak 2021].

https://www.youtube.com/watch?v=W6y-aAjpQKs\&ab_channel=24News, [Erişim tarihi: 9 Kasim 2020].

https://www.ensonhaber.com/galeri/istanbulda-olayli-1-mayis-kutlamasi, [Erişim tarihi: 11 Kasım 2020].

https://www.youtube.com/watch?v=V- hBeclYP9g\&ab_channel=24News, [ Erişim tarihi: 26 Kasım 2020].

https://www.crystalinks.com/ar.html, [Erişim tarihi: 22 Eylül 2020].

https://www.youtube.com/watch?v=_Idy0izevN8, [Erişim tarihi: 22 Eylül 2020]. 